\title{
Economic Evaluation of the Production of Perennial Crops for Energy Purposes-A Review
}

\author{
Ewelina Olba-Zięty *(1), Mariusz Jerzy Stolarski $\mathbb{1}$ and Michał Krzyżaniak
}

Citation: Olba-Zięty, E.; Stolarski,

M.J.; Krzyżaniak, M. Economic

Evaluation of the Production of

Perennial Crops for Energy

Purposes-A Review. Energies 2021,

14, 7147. https://doi.org/10.3390/

en14217147

Academic Editor: Fernando Rubiera González

Received: 7 October 2021

Accepted: 25 October 2021

Published: 1 November 2021

Publisher's Note: MDPI stays neutral with regard to jurisdictional claims in published maps and institutional affiliations.

Copyright: (C) 2021 by the authors. Licensee MDPI, Basel, Switzerland. This article is an open access article distributed under the terms and conditions of the Creative Commons Attribution (CC BY) license (https:/ / creativecommons.org/licenses/by/ $4.0 /)$.
Department of Genetics, Plant Breeding and Bioresource Engineering, Faculty of Agriculture and Forestry, Centre for Bioeconomy and Renewable Energies, University of Warmia and Mazury in Olsztyn, 10-724 Olsztyn, Poland; mariusz.stolarski@uwm.edu.pl (M.J.S.); michal.krzyzaniak@uwm.edu.pl (M.K.)

* Correspondence: e.olba-ziety@uwm.edu.pl; Tel.: +48-895-245-329

\begin{abstract}
Biomass is widely used for the production of renewable energy, which calls for an economic evaluation of its generation. The aim of the present work was to review the literature concerning the economic evaluation of the production of perennial crop biomass for energy use. Statistical analysis of the bibliographic data was carried out, as well as an assessment of methods and values of economic indicators of the production of perennial crops for bioenergy. Most of the papers selected for the review were published in the years 2015-2019, which was probably stimulated by the growing interest in sustainable development, particularly after 2015, when the United Nations declared 17 sustainable development goals. The earliest articles concerned the economic analysis of plantations of short rotation coppice; the subsequent ones included the analysis of feedstock production in terms of the net present value and policy. The latest references also investigated transport and sustainability issues. The crops most commonly selected for production cost analysis were willow, poplar, and Miscanthus. The cost of production of willow and poplar were similar, 503 EUR ha ${ }^{-1}$ year $^{-1}$ and 557 EUR ha ${ }^{-1}$ year $^{-1}$, respectively, while the cost of Miscanthus production was significantly higher, $909 \mathrm{EUR} \mathrm{ha}^{-1}$ year $^{-1}$ on average. By analogy, the distribution of revenue was similar for willow and poplar, at $236 \mathrm{EUR} \mathrm{ha}^{-1}$ year $^{-1}$ and $181 \mathrm{EUR} \mathrm{ha}^{-1}$ year $^{-1}$; Miscanthus production reached the value of 404 EUR ha $^{-1}$ year $^{-1}$. The economic conditions of perennial crop production differed in terms of geography; four areas were identified: Canada, the USA, southern Europe, and central and northern Europe.
\end{abstract}

Keywords: economic analysis; perennial crops; willow; poplar; Miscanthus; bioenergy; bibliometric networks

\section{Introduction}

The growing demand for renewable energy has spurred interest in biomass as an energy source [1]. Biomass has been widely used for the generation of renewable energy $[2,3]$. However, the development of the concept of sustainability, in which care for the environment is as important as economic and social progress, means that biomass should be produced at the lowest production cost possible with the smallest negative impact on the environment [4]. If new, stable jobs can be created in the process, all the criteria of sustainable development seem to be satisfied. The conducted analyses indicate that it is possible to meet the demand for biofuel and biomass with no impact on food production [5], especially when the production of crops is carried out on marginal land or biomass is production waste [6-13].

Another concept that has gained significance in recent years is the development of bioeconomy, or economy based on biomass materials. This is another trend that has triggered interest in biomass for purposes other than food and feed [14]. The distribution of produced biomass has also changed over the last years. Besides production for food and feed, its importance has grown as a resource for generating thermal energy $[15,16]$, electricity [1,17-19], solid biofuels [20,21], biogas [12,13,22-24], and bioethanol [25-29]. The 
development of the concept of multiproduct biorefineries and the cascading use of biomass led to interest in perennial crops, including short rotation coppice (SRC) or grasses, also grown for other purposes, e.g., to make biochemicals $[30,31]$ or bioactive substances used as raw material for pharmaceutical or veterinary bioproducts [32,33].

The search for crops that would meet the criteria of sustainable development and make good raw material for bioenergy and bioeconomy has been the subject of numerous papers [34-36], many of which determined specific conditions for their cultivation [37], harvest [38-47], and factors affecting the crop per area unit [48] and the impact of cultivation on greenhouse gases (CHG) [49,50] and on the environment [51-53]. Mathematical methods were used by Bender et al. [54], Hauk et al. [55], Salles et al. [56], and Sleight et al. [57,58] to assess crop yields; by Havlíčková et al. [59] to assess the SRC biomass price; and by Frank et al. [60] to assess both the minimum selling price and net present value (NPV). One of the main factors affecting the selection of perennial crops for commercial use for energy or bioproduction purposes, apart from the volume of yields, was the economic profitability of production, which has always had a decisive influence on the farmer's decision to engage or not to engage in the cultivation of this kind of crop. It should obviously be emphasized that the final economic effectiveness of biomass production of a certain crop is a function of many factors: the cost incurred in production; amount of biomass crop; lifespan of a plantation; price of biomass; its logistics and final use; and other, local, regional, or even domestic conditions. Because of these local conditions, the effectiveness of biomass production from a specific perennial crop in one site does not absolutely mean that the same results will be achieved in another. The relevant literature lacks references providing a synthetic presentation of issues related to the economic effectiveness of biomass production from perennial crops. Hence, the aim of this study was to review the literature dedicated to the economic evaluation of biomass production from perennial crops for energy purposes, including the determination of (i) the temporal and geographic distribution of publications; (ii) a list of journals where these issues appeared; (iii) a cluster distribution of the scope of the publications; (iv) key word analysis; and (v) the value of certain indicators of economic viability of production, namely the cost $\left(E U R \mathrm{Mg}^{-1}\right.$ d.m.; EUR ha ${ }^{-1}$ year $^{-1}$, EUR GJ $\left.{ }^{-1}\right)$, price (EUR $\mathrm{Mg}^{-1}$ d.m.), break-even price (BEP) (EUR $\mathrm{Mg}^{-1}$ d.m.), revenue as the NPV of an annual annuity, and the internal rate of return (IRR).

\section{Materials and Methods}

The analytical material for our research and analysis was composed of 180 scientific articles found in the Scopus and Web of Science databases on the basis of the key words perennial crops, bioenergy, economic assessment, and production cost and published between 2000 and the first half of 2021.

Based on all collected data, the number of articles was calculated for particular years within the studied period and countries where the economic evaluation of perennial crops for energy was carried out. Next, an analysis of the journals in which the issue of the economic evaluation of perennial crops for energy was raised was carried out. This analysis was also based on all of the articles.

Subsequently, all 180 selected articles were classified according to the bibliographical data with the use of VOSviewer software [61,62]. VOSviewer is an instrument for analysis and map generation based on the bibliographical records of publications [63]. On the basis of the extent of co-occurrence of terms included in headings and key words, the program generated links between the terms. The resulting network was a collection of elements together with interconnected terms. Next, the terms, referred to as items, were grouped into clusters that did not overlap, and in which a given item appeared only once. On the basis of the frequency of incidence, particular items were assigned weights, which were marked with bigger circles and denoted in a bigger font on the map. The color of the element marked the cluster where the element belonged. The lines between the items represented links. The distance between two terms in the visualization approximately indicated the relatedness of the terms in publication links. The closer they are, the stronger 
the relationship and a more frequent co-occurrence. In this manner, network visualization and overlay visualization maps were built. The second map was identical with network visualization but was shown in different colors, which did not serve to identify the clusters but referred to the year of article publication, to present the temporal variability of terms within the clusters. The analysis was conducted with the use of a clustering technique; the association strength method was used for normalizing the strength of the links between the items.

The following stage consisted of an analysis of the key words, which enabled us to distinguish 140 out of 180 gathered articles in which the analyzed key words were identified. It was conducted to identify and record the frequency of the term 'perennial crops' in scientific articles, as well as the frequency of occurrence of the key words, including economic indicators and methods of economic evaluation of the analyzed perennial crops.

Out of all collected research articles, groups of articles were distinguished to make the following analysis: lifespan of a plantation (21 papers); crop yield (Mg d.m. ha ${ }^{-1}$ year $^{-1}$ ) (27 papers); and indicators of economic evaluation, i.e., production cost (EUR $\mathrm{Mg}^{-1}$ d.m.; EUR ha ${ }^{-1}$; EUR GJ ${ }^{-1}$ ) (55 papers), break-even price (BEP) (EUR Mg d.m.) (21 papers), sale price (EUR $\mathrm{Mg}^{-1}$ d.m.; EUR GJ ${ }^{-1}$ ) (35 papers), annual annuity NPV as revenue (EUR ha ${ }^{-1}$ year $^{-1}$ ) (55 papers), and IRR (\%) (20 papers), referred to here as indicators. This analysis took into account the characteristics that were numerically defined in the articles. Only positive values were considered for the annual annuity NPV and IRR. The authors are aware that the production of willow, poplar, and Miscanthus is often unprofitable, in particular on low-quality land [64-66]. We strove, however, to present an average value of the revenue if the cultivation yields any profit.

For the collected indicators of the economic evaluation of production, descriptive statistics were calculated: valid $\mathrm{N}$, mean, median, lower quartile, upper quartile, standard deviation, and coefficient of variation. One-way analysis of variance was employed for statistical analysis. The significance of differences between the means was tested with the Tukey HSD test for different $\mathrm{N}$ at $p<0.05$.

The obtained numeric values for the selected indicators were also analyzed for similarities between the countries under study. A multidimensional cluster analysis (CA) was employed; agglomeration was carried out with the Ward method, and the Euclidean distance was used as a unit of distance. The cut-off significance was based on the Sneath index at $33 \%$. All of the above calculations were conducted in a STATISTICA 13.3 package (TIBCO Software Inc., Palo Alto, CA, USA, 2017).

\section{Results and Discussion}

\subsection{Time and Spatial Analysis}

The analysis covered 180 scientific articles published between 2000 and mid-2021 (Figure 1). Most of the papers concerning the economic evaluation of perennial crop production for energy purposes were published between 2015 and 2019, although many of them also came out in 2012. The first ten years of the period under study showed little interest in this area, and the number of published papers corresponded to $12 \%$ of the total number.

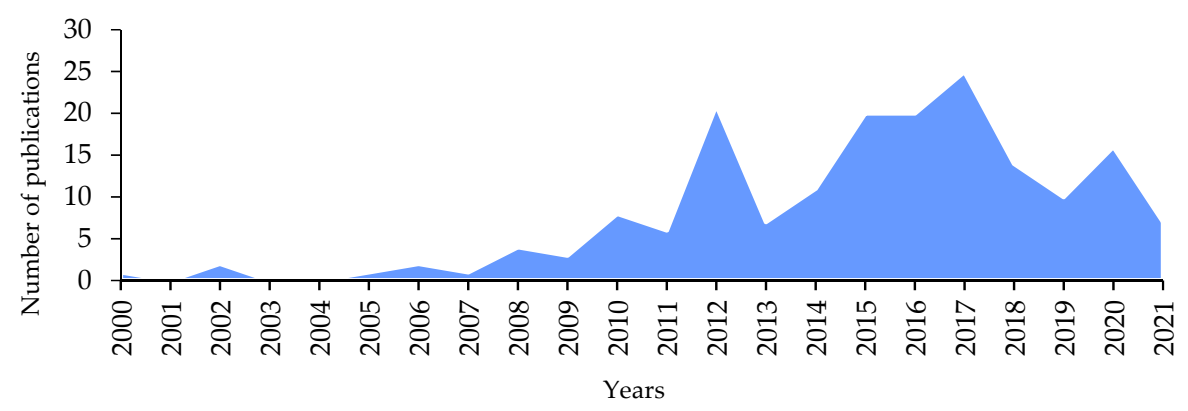

Figure 1. Temporal analysis of papers concerned with economic analysis of perennial crops for energy. 
Economic analysis of perennial crops was a subject of interest among researchers from Europe, mainly those from Germany [10,13,65,67,68], Italy [69-71], Poland [72-75], and the Netherlands [76,77] (Figure 2). In addition, these issues were also dealt with by authors from the USA [60,78-81] and Canada [8,16,25,82]. Much fewer articles on this subject were published by researchers from Asia and South America, which may be due to the smaller extent of perennial crop cultivation or less interest in the use of dedicated energy crops for bioenergy.

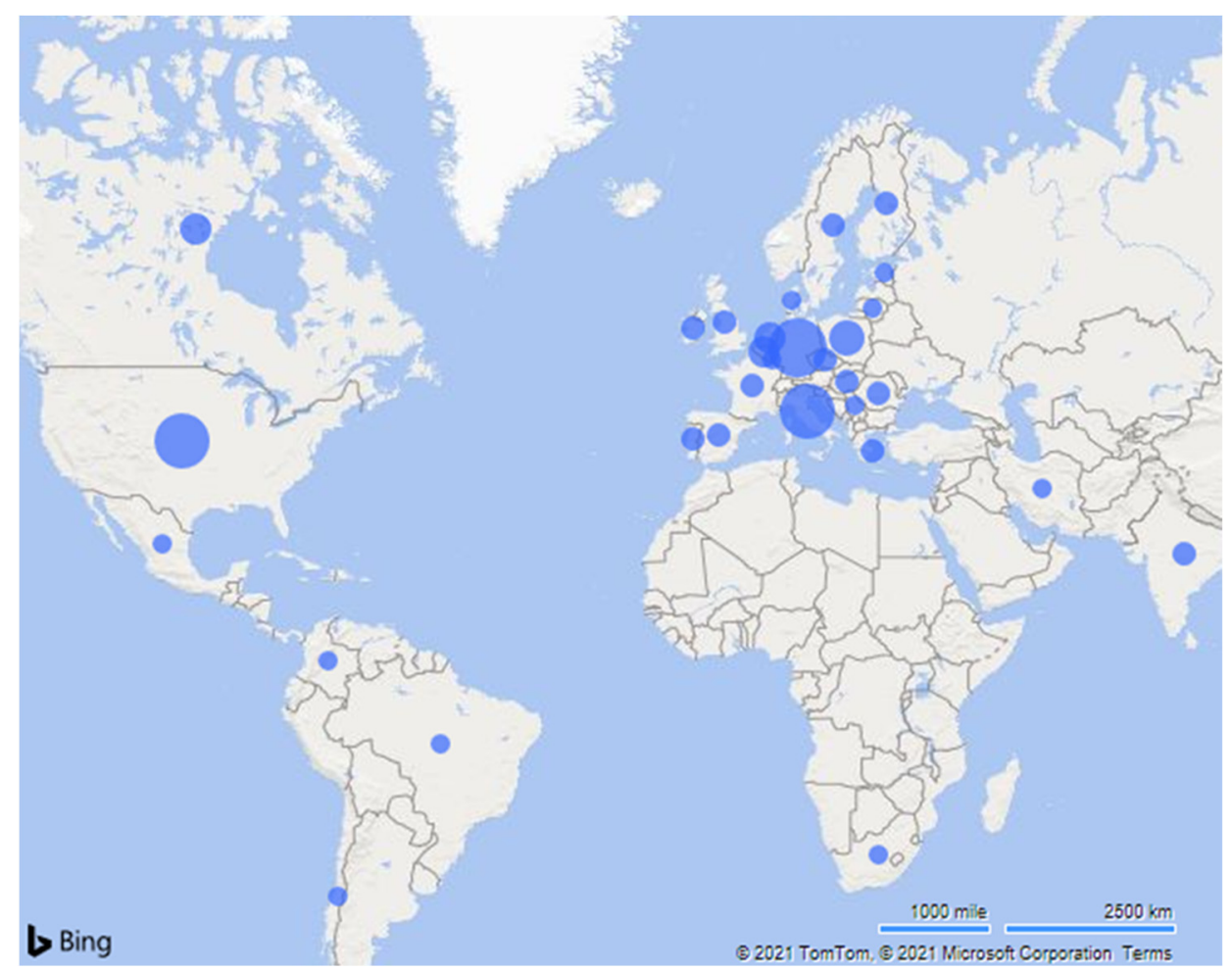

Figure 2. Map of papers' authors by country of origin with regard to papers concerned with economic analysis of perennial crops for energy.

\subsection{Journal Analysis}

The vast majority of the papers were published in journals that deal with the issues of biomass, bioenergy, and sustainability. The following journals came to the fore: Biomass and Bioenergy ( 45 papers, $25 \%$ ), Renewable and Sustainable Energy Reviews (14 papers, $8 \%$ ), and GCB Bioenergy (10 papers, $6 \%$ ) (Figure 3). Nine papers each were published in BioEnergy Research, Journal of Cleaner Production, and Renewable Energy. The 6 journals enumerated above contained over $50 \%$ of the analyzed articles; the articles were published in a total number of 62 journals. 


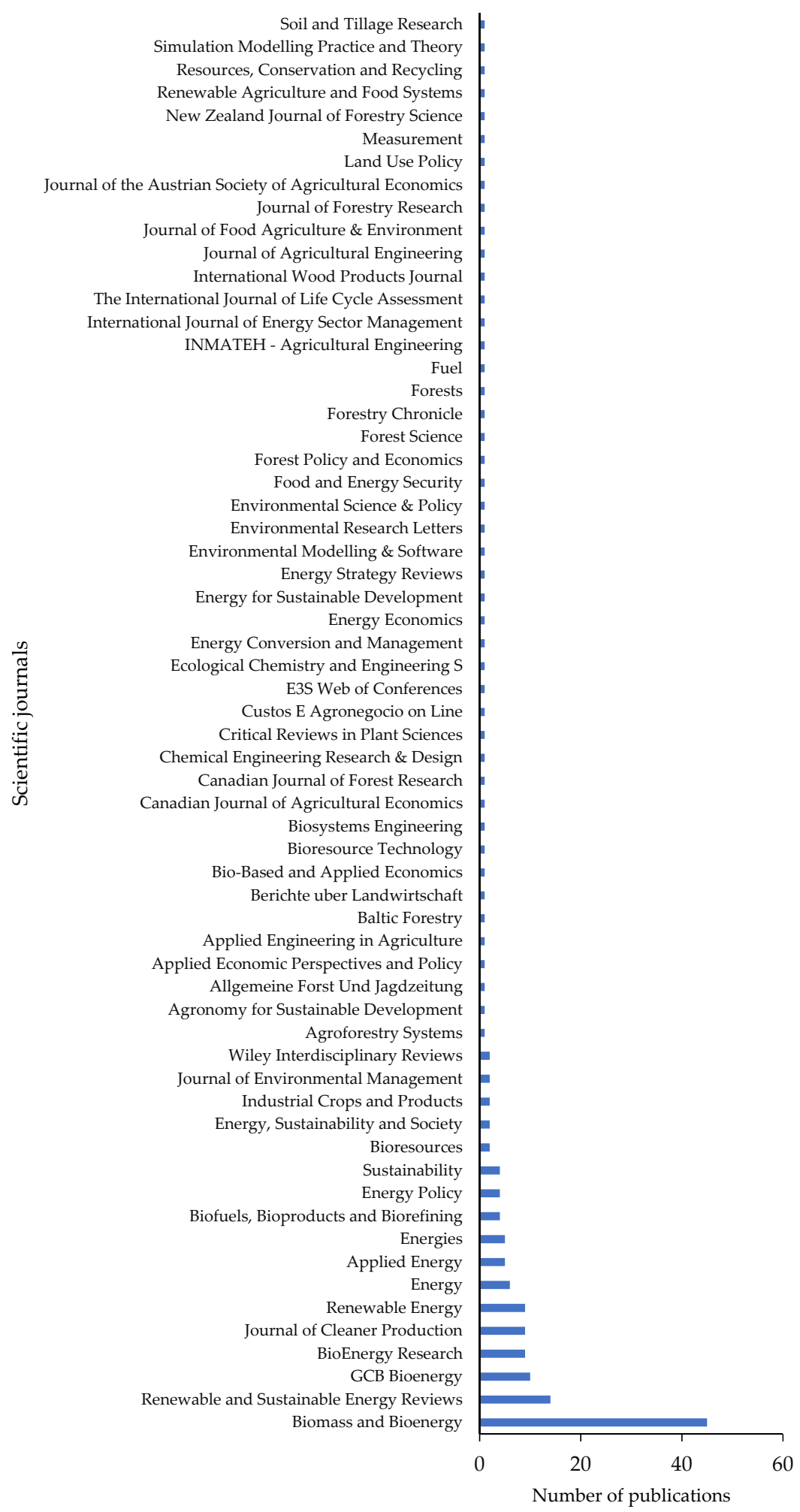

Figure 3. Scientific journals presenting papers that covered economic analysis of perennial crops for energy.

\subsection{Cluster Analysis}

The analysis of the 180 research papers with the use of network visualization enabled us to divide them into three clusters (Figure 4). The first cluster represented the cooccurrence of studies on the cultivation and price in relation to bioenergy, economic analysis, short rotation coppice, and net present value. Moreover, the result of the analysis 
drew attention to switchgrass, another crop that was a subject of interest among the studied authors. The issue of cultivation was shifted to another cluster, where questions on feedstock were dealt with alongside policy, reduction, and supply chain in terms of environmental performance. This approach was close to what was classified into the third cluster, dominated by issues of the environment in energy production and problems that were most often raised here, such as sustainability, life cycle assessment, heat, electricity, biogas, and power, with emphasis on papers analyzing Miscanthus.

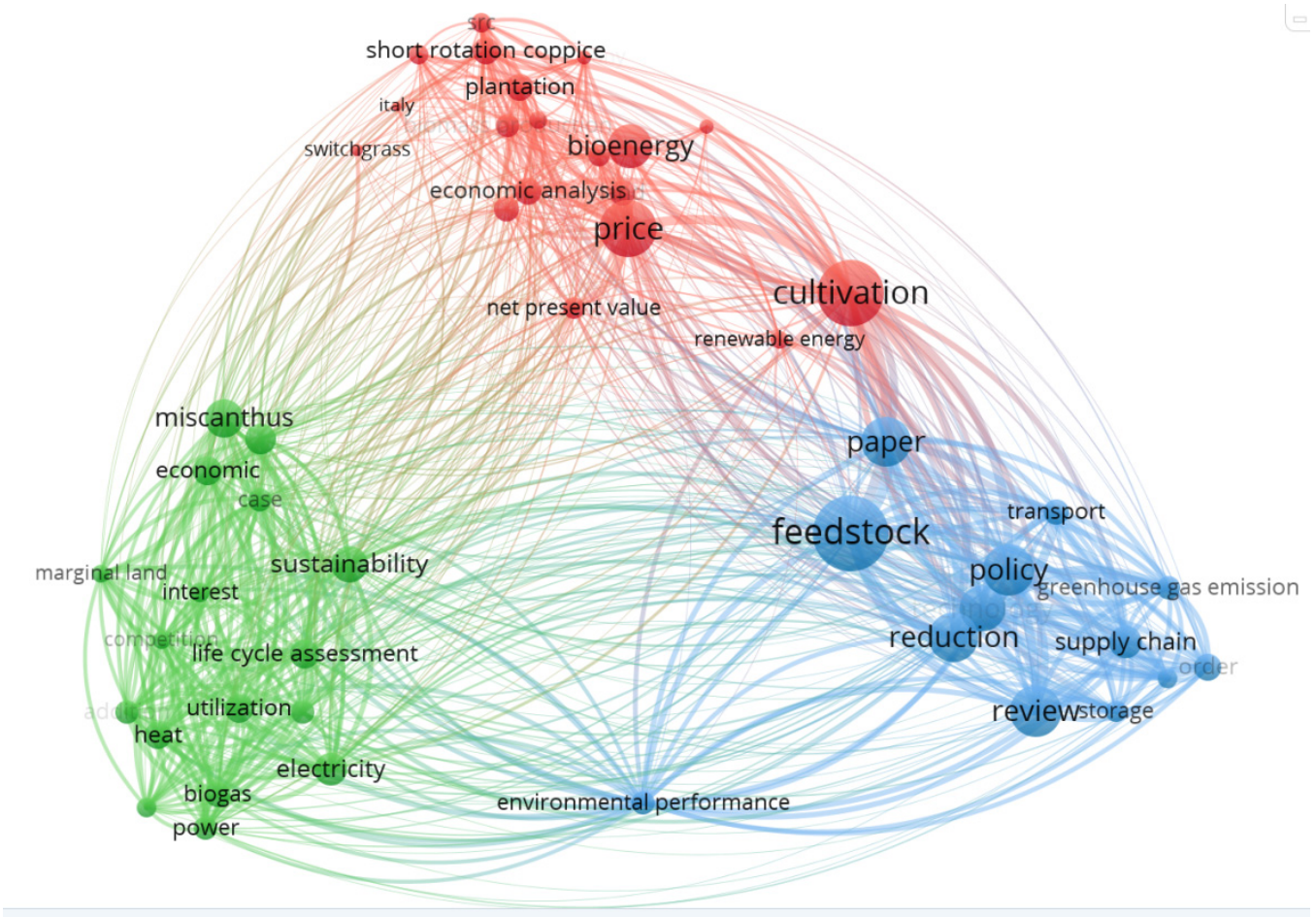

Figure 4. Network visualization of papers selected for analysis.

An overlay visualization analysis helped us to explore the temporal variation of the scope of the papers. Most of the papers selected for analysis were published in the years 2015-2019 (Figure 1), and, thus, the analysis of co-occurrence covered mainly that period. Within that time, the earliest papers issued in 2015 concerned the range of the economic analyses of plantation short rotation coppice; later papers (2016) dealt with Miscanthus, cultivation, and price; and the papers published around 2017 analyzed feedstock in terms of net present value and policy, as well as bioenergy generation, electricity, and heat in particular. Papers published in 2018 also looked at transport and sustainability. In the latest works of 2019, the investigated issues included environmental performance, life cycle assessment, and technology (Figure 5). 


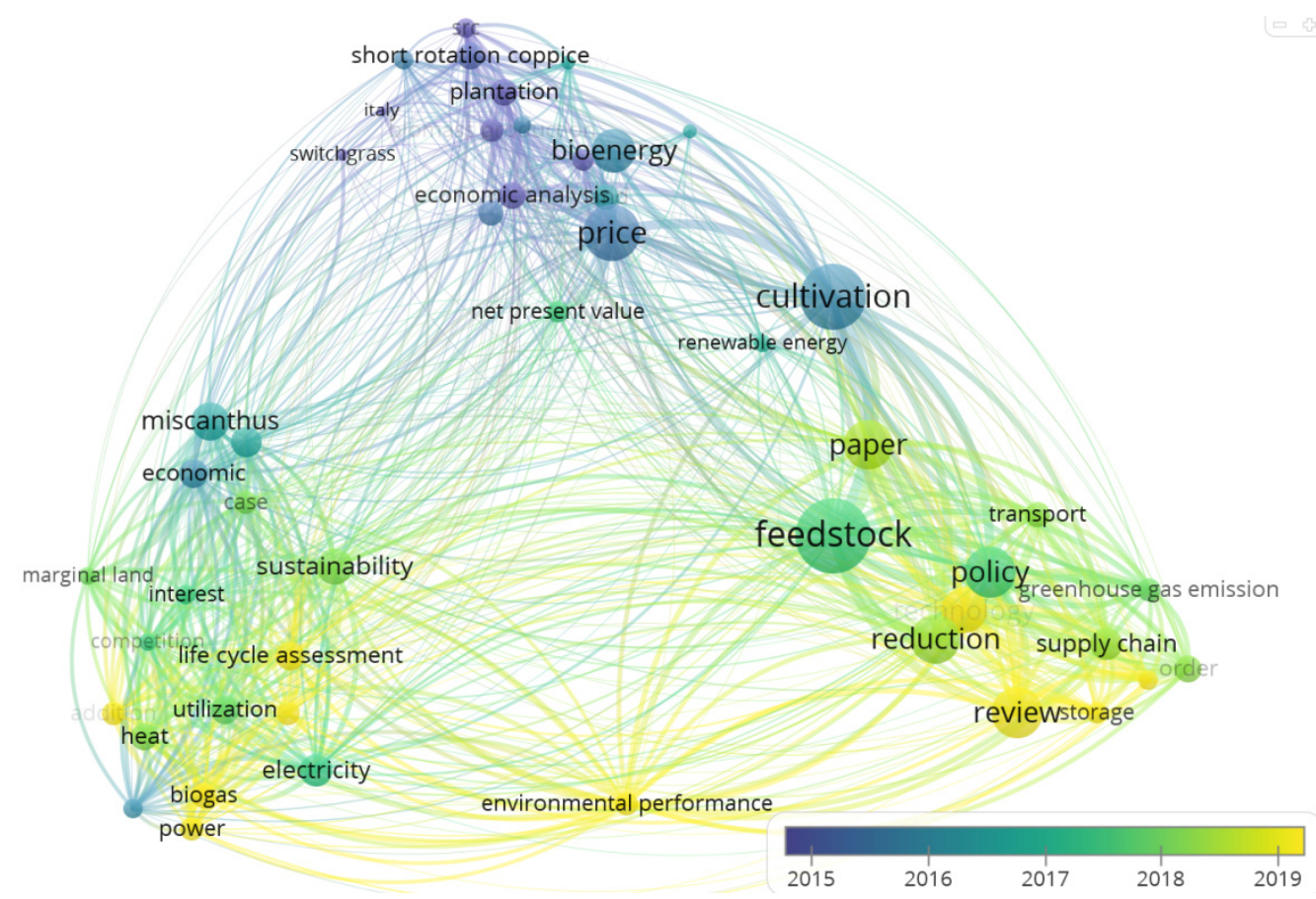

Figure 5. Overlay visualization of papers selected for analysis.

\subsection{Analysis of Crop Species}

The analysis of crop species (Figure 6) suggested that the crops most often mentioned and analyzed in the selected papers were willow (Salix spp.) in 38 papers, poplar (Populus spp.) in 30 papers, and Miscanthus spp. in 22 papers. Hence, the analysis of selected economic indicators presented here focused on these three crops. Other crop species appeared in the papers much less frequently. Some of the papers also investigated the economy of growing annual crops, but these were mainly seen as reference crops.

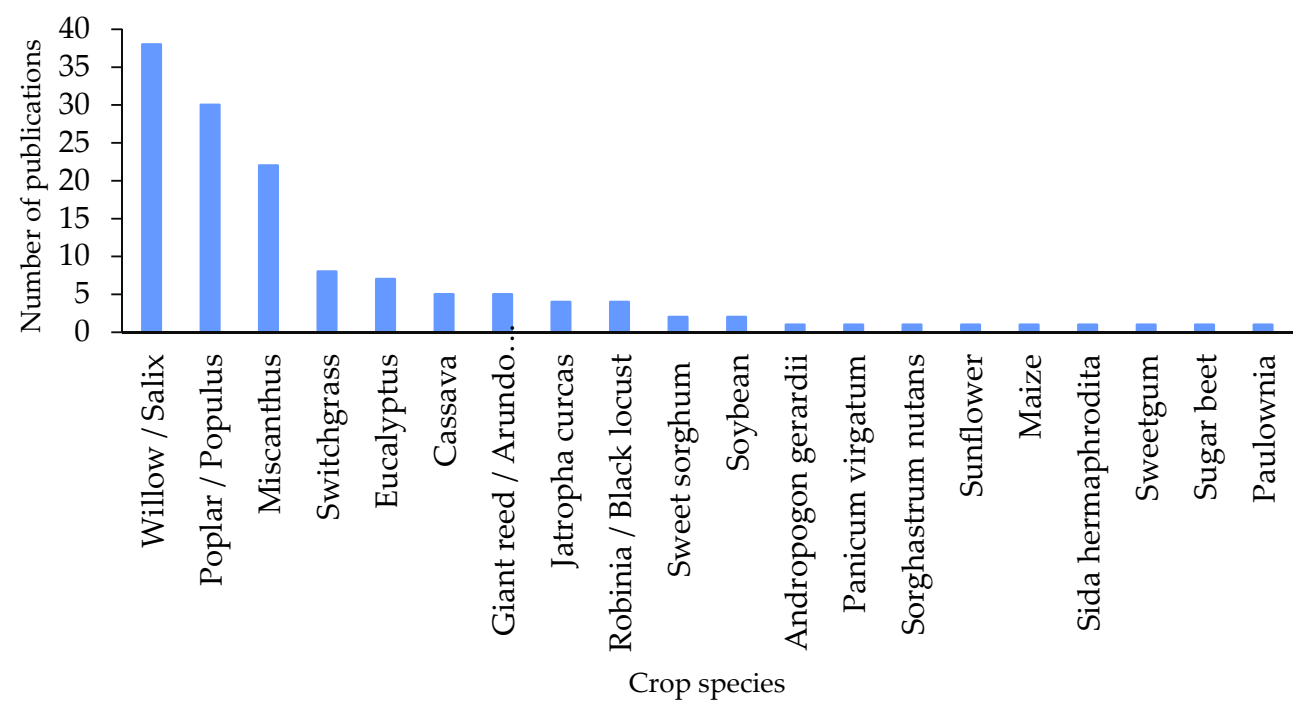

Figure 6. Frequency of references to crop species in articles concerned with economic analysis of perennial crops for energy.

\subsection{Analysis of Methods for Economic Evaluation of Perennial Crop Production}

The performed analysis of the key words enabled us to identify various research approaches to the economic evaluation of perennial crop production. Figure 7 shows the most common key words, of which the most frequently appearing ones were eco- 
nomics/economic analysis/economic assessment and then the term 'cost'. The cost of production of perennial crops was presented in three frames of reference: per $1 \mathrm{Mg}$ of dry mass (d.m.) $[17,25,83-86]$, per 1 ha of production $[49,72,83,84,86,87]$, and per $1 \mathrm{GJ}$ energy in biomass $[17,26,73,75,88-90]$.

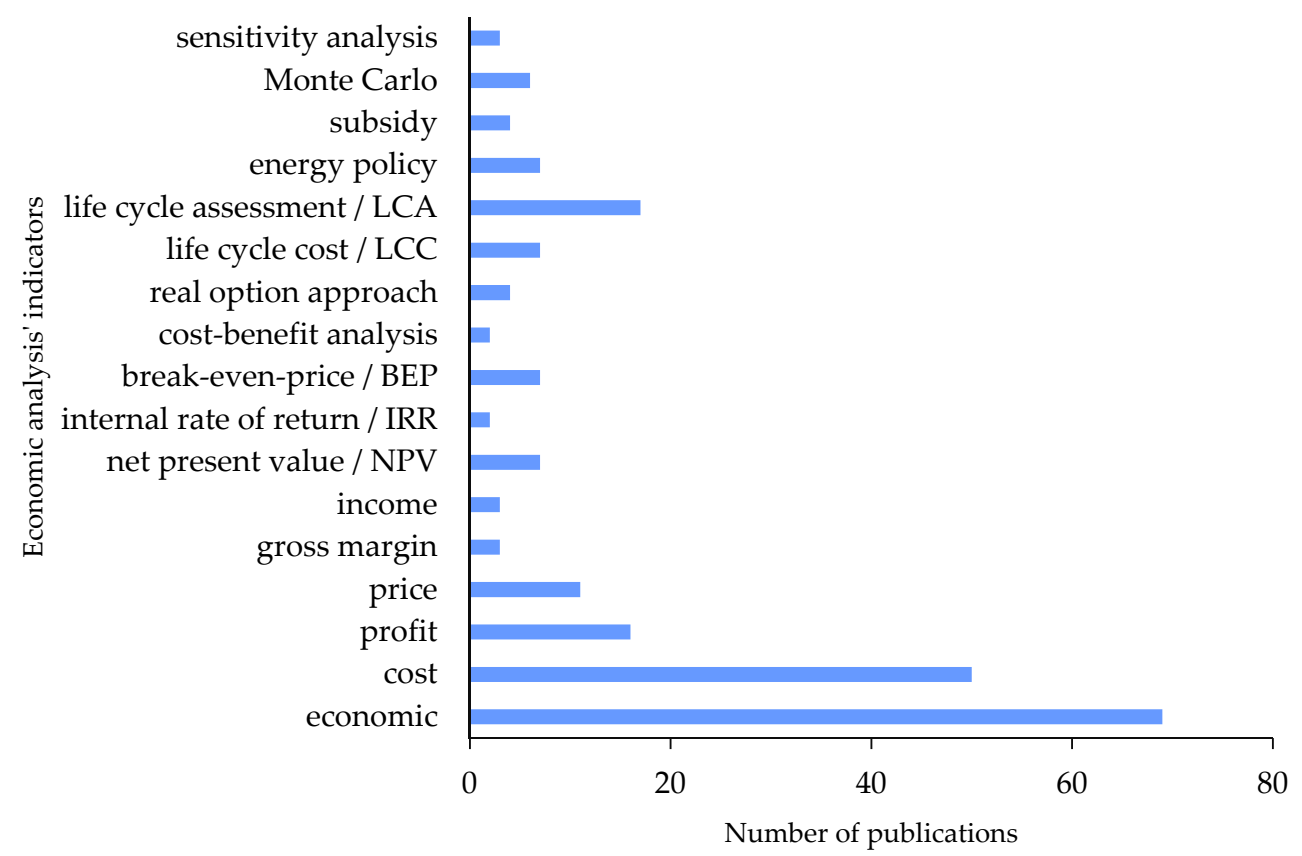

Figure 7. Frequency of incidence among particular indicators of economic analysis in the selected papers.

The economic evaluation of perennial crop production was treated as an investment, so economic indicators were used to assess its profitability. The most often calculated indicator of perennial crop production viability was the net present value (NPV), which was expressed in the key words $[15,85,91-93]$ or the NPV of an annuity understood as revenue per year $[73,75,84,93-96]$.

Another economic indicator was the internal rate of return (IRR), which seldom appeared as a key term but was found as an indicator in several papers [10,97-101]. Some of the economic analyses of production led to the determination of the break-even price (BEP), which indicates the break-even point $[11,15,19,79,97,100,102-106]$. There were also papers where break-even yield (BEY) was determined [93].

An extension of the economic analysis found in several papers was a life cycle cost assessment, also referred to as life cycle costing (LCC) [11,96]. The development and ever wider use of the life cycle assessment of production SRC $[53,107,108]$ created an opportunity to evaluate the economic impact on the environment [21,101,109-112]. Other papers dealt with life cycle sustainability assessment (LSCA), where social issues were part of the evaluation [113].

Another method of economic evaluation was the cost-benefit analysis (CBA) [16,20]. A real options approach was yet another method used for this type of evaluation [104,114,115]. Some of the papers also took into account the conditions of support/subsidies and energy policy affecting the profitability of production $[79,91,94,116-118]$.

Another important aspect of the papers was a sensitivity analysis, conducted in many of the articles as an analysis of scenarios involving a change in the parameters of the price of biomass or crop yield in the range of $\pm 5,10$, and $15 \%$, [49,72,95,101,102,119]; another method employed for specific purposes was Monte Carlo analysis [56,120-122]. 


\subsection{Analysis of the Value of Economic Indicators}

Plantations of perennial crops were set up for 19 years on average, and the median was 20 years (Table 1). The highest crop yield was obtained from Miscanthus, $29.81 \mathrm{Mg} \mathrm{ha}^{-1}$ year ${ }^{-1} \mathrm{~d} . \mathrm{m}$. on average. On the other hand, the yields from willow and poplar were significantly lower and similar to each other (the same homogenous group), reaching 10.71 and $9.68 \mathrm{Mg} \mathrm{ha}^{-1}$ year $^{-1}$ d.m., respectively (as confirmed by the ANOVA results at $p>0.05)$.

Table 1. Descriptive statistics of economic value indicators in the papers selected for analysis.

\begin{tabular}{|c|c|c|c|c|c|c|c|c|}
\hline Variable & Crop & Valid N & Mean & Median & $\begin{array}{c}\text { Lower } \\
\text { Quartile }\end{array}$ & $\begin{array}{c}\text { Upper } \\
\text { Quartile }\end{array}$ & $\begin{array}{l}\text { Stand } \\
\text { Dev. }\end{array}$ & $\begin{array}{l}\text { Coef. of } \\
\text { Var. }\end{array}$ \\
\hline \multirow{4}{*}{$\begin{array}{l}\text { Lifespan } \\
\text { (year) }\end{array}$} & willow & 31 & 20.08 & 20.00 & 20.00 & 22.00 & 2.63 & 13.08 \\
\hline & poplar & 20 & 18.18 & 20.00 & 15.00 & 20.00 & 3.72 & 20.46 \\
\hline & Miscanthus & 12 & 21.11 & 18.00 & 15.50 & 26.00 & 6.89 & 35.09 \\
\hline & Sum $^{\mathrm{a}} /$ mean & $63^{a}$ & 19.39 & 20.00 & 16.00 & 22.00 & 4.43 & 33.46 \\
\hline \multirow{4}{*}{$\begin{array}{c}\text { Yield } \\
\left(\mathrm{Mg} \mathrm{ha}^{-1}\right. \\
\left.\text { year }^{-1} \text { d.m. }\right)\end{array}$} & willow & 44 & 10.71 * & 10.00 & 8.86 & 12.00 & 3.38 & 31.61 \\
\hline & poplar & 14 & $9.68 *$ & 9.28 & 8.51 & 10.00 & 2.87 & 29.62 \\
\hline & Miscanthus & 24 & $29.81^{* *}$ & 26.58 & 24.80 & 38.40 & 10.31 & 34.59 \\
\hline & Sum ${ }^{a} /$ mean & $82^{a}$ & 16.12 & 11.12 & 9.08 & 23.90 & 10.78 & 66.86 \\
\hline \multirow{4}{*}{$\begin{array}{c}\text { Cost } \\
\text { (EUR } \mathrm{Mg}^{-1} \\
\text { d.m.) }\end{array}$} & willow & 22 & 60.09 & 62.13 & 54.00 & 65.70 & 13.88 & 23.10 \\
\hline & poplar & 14 & 69.70 & 73.05 & 60.90 & 77.50 & 17.16 & 24.62 \\
\hline & Miscanthus & 19 & 95.09 & 76.90 & 44.95 & 94.64 & 89.86 & 94.50 \\
\hline & Sum ${ }^{a} /$ mean & $55^{\mathrm{a}}$ & 74.63 & 64.60 & 54.00 & 77.50 & 55.47 & 74.33 \\
\hline \multirow{4}{*}{$\begin{array}{c}\text { Cost } \\
\left(\text { EUR ha }^{-1}\right)\end{array}$} & willow & 64 & 503.53 * & 442.50 & 236.82 & 668.15 & 328.65 & 65.27 \\
\hline & poplar & 26 & $557.23 *$ & 555.96 & 498.61 & 635.85 & 168.78 & 30.29 \\
\hline & Miscanthus & 32 & $909.07^{* *}$ & 1071.51 & 697.31 & 1071.51 & 314.09 & 34.55 \\
\hline & Sum $^{a} /$ mean & $122^{\mathrm{a}}$ & 621.35 & 567.40 & 375.00 & 878.20 & 342.81 & 55.17 \\
\hline \multirow{4}{*}{$\begin{array}{c}\text { Cost } \\
\left(\text { EUR GJ }^{-1}\right)\end{array}$} & willow & 30 & 3.36 & 3.27 & 2.70 & 3.80 & 1.48 & 44.09 \\
\hline & poplar & 12 & 3.70 & 3.60 & 3.10 & 3.95 & 1.32 & 35.55 \\
\hline & Miscanthus & 2 & 3.55 & 3.55 & 2.30 & 4.80 & 1.77 & 49.80 \\
\hline & Sum ${ }^{a} /$ mean & $44^{\mathrm{a}}$ & 3.46 & 3.29 & 2.75 & 3.90 & 1.42 & 41.05 \\
\hline \multirow{4}{*}{$\begin{array}{c}\text { BEP } \\
\text { (EUR } \mathrm{Mg}^{-1} \\
\text { d.m.) }\end{array}$} & willow & 20 & 118.93 & 135.14 & 118.00 & 146.15 & 47.98 & 40.34 \\
\hline & poplar & 6 & 181.51 & 161.00 & 118.00 & 240.67 & 72.58 & 39.99 \\
\hline & Miscanthus & 26 & 97.19 & 87.67 & 73.76 & 93.31 & 56.48 & 58.11 \\
\hline & Sum ${ }^{a} /$ mean & $52^{\mathrm{a}}$ & 113.36 & 94.43 & 74.29 & 141.63 & 61.23 & 54.01 \\
\hline \multirow{4}{*}{$\begin{array}{c}\text { Price } \\
\text { (EUR } \mathrm{Mg}^{-1} \\
\text { d.m.) }\end{array}$} & willow & 34 & 81.58 & 82.25 & 70.98 & 84.50 & 26.69 & 32.71 \\
\hline & poplar & 15 & 82.02 & 81.60 & 81.40 & 90.00 & 11.24 & 13.71 \\
\hline & Miscanthus & 25 & 107.99 & 93.46 & 62.70 & 134.00 & 61.69 & 57.13 \\
\hline & Sum ${ }^{\mathrm{a}} /$ mean & $74^{\mathrm{a}}$ & 90.59 & 82.10 & 71.00 & 100.00 & 41.88 & 46.23 \\
\hline \multirow{4}{*}{$\begin{array}{c}\text { Price } \\
\left(\text { EUR GJ }^{-1}\right)\end{array}$} & willow & 6 & 3.22 & 2.80 & 1.68 & 3.70 & 1.93 & 59.71 \\
\hline & poplar & 1 & 4.40 & 4.40 & 4.40 & 4.40 & 0.00 & 0.00 \\
\hline & Miscanthus & 1 & 3.17 & 3.17 & 3.17 & 3.17 & 0.00 & 0.00 \\
\hline & Sum ${ }^{a} /$ mean & $8^{a}$ & 3.36 & 3.06 & 2.16 & 4.05 & 1.68 & 49.94 \\
\hline \multirow{4}{*}{$\begin{array}{c}\text { Revenue } \\
\left(\text { EUR ha }^{-1}\right. \\
\left.\text { year }^{-1}\right)\end{array}$} & willow & 69 & 236.30 * & 245.00 & 137.23 & 296.00 & 129.26 & 54.70 \\
\hline & poplar & 13 & $180.91 *$ & 143.00 & 66.90 & 193.90 & 219.95 & 121.58 \\
\hline & Miscanthus & 19 & $404.11^{* *}$ & 383.00 & 326.00 & 519.00 & 124.79 & 30.88 \\
\hline & Sum ${ }^{a} /$ mean & $101^{\mathrm{a}}$ & 260.74 & 252.10 & 143.00 & 335.00 & 158.48 & 60.78 \\
\hline \multirow{4}{*}{$\begin{array}{l}\text { IRR } \\
(\%)\end{array}$} & willow & 10 & 18.28 & 15.70 & 13.80 & 25.30 & 7.01 & 38.37 \\
\hline & poplar & 8 & 11.14 & 9.40 & 7.50 & 16.05 & 4.48 & 40.21 \\
\hline & Miscanthus & 2 & 15.00 & 15.00 & 10.00 & 20.00 & 7.07 & 47.14 \\
\hline & Sum a /mean & $20^{\mathrm{a}}$ & 15.10 & 14.80 & 10.00 & 18.40 & 6.73 & 44.56 \\
\hline
\end{tabular}


The average cost of producing $1 \mathrm{Mg}^{-1} \mathrm{~d} . \mathrm{m}$. ranged from 60 EUR $\mathrm{Mg}^{-1} \mathrm{~d} . \mathrm{m}$. for willow to 70 EUR $\mathrm{Mg}^{-1}$ d.m. for poplar to $95 \mathrm{EUR} \mathrm{Mg}^{-1}$ d.m. for Miscanthus. Xue [87] noted that despite the high yields and low production cost of some species of Miscanthus, the expensive breeding techniques were a barrier to its widespread cultivation. The cost of production of Miscanthus was characterized by the highest variance, which is corroborated by the high value of standard deviation (89.86) and variance coefficient of $94.5 \%$. For willow and poplar, the values of these two indicators were around fourfold lower.

The cost of producing perennial crops per 1 ha of acreage was one of the aspects most frequently studied in the papers. This cost was similar for willow and poplar, which belonged to the same homogenous group (as confirmed by the ANOVA results at $p>0.05$ ), and reached around $500 \mathrm{EUR} \mathrm{ha}^{-1}$ year $^{-1}$ and $550 \mathrm{EUR} \mathrm{ha}^{-1}$ year $^{-1}$, respectively. In turn, the average cost of the production of Miscanthus was significantly higher (Miscanthus belonged to another homogenous group) and stood at approximately $900 \mathrm{EUR} \mathrm{ha}^{-1} \mathrm{year}^{-1}$. The cost of 1 GJ energy contained in biomass was similar for all the three types of crops and amounted to $3.46 \mathrm{EUR} \mathrm{GJ}^{-1}$ on average. The sale price quoted in the analyzed publications was also similar, averaging at EUR $90 \mathrm{Mg}^{-1}$ d.m.; however, the values of the break-even price (BEP) differed quite widely; the highest average value was noted for poplar production (181.51 EUR $\mathrm{Mg}^{-1}$ d.m.), but with a greater valid $\mathrm{N}$ number, this value could have been different. The value of BEP for willow stood at $118.93 \mathrm{EUR} \mathrm{Mg}^{-1} \mathrm{~d} . \mathrm{m}$. and was the lowest for Miscanthus, at 97.19 EUR $\mathrm{Mg}^{-1} \mathrm{~d} . \mathrm{m}$. Such a great difference between the market price and BEP followed from the high variation of production conditions. Many studies described the plantations of perennial crops as being on low-quality soil, marginal land, or land of large inclination, where the yield of biomass was very low. This is why the production was unprofitable and the value of BEP was high, which in turn affected the average BEP value obtained in our review of the literature data.

The production profitability analysis with the use of the value of revenue, which was calculated on the basis of the NPV, namely as the NPV of an annual annuity for positive values, was characterized by the highest variability. This probably followed from the high variability of these values in the literature and the assumption to make analyses for positive values, although both negative and positive values can be found in the literature. Hauk et al. [58], on the basis of a literature review, indicated that out of 37 papers concerning the economic evaluation of short rotation coppice production, $43 \%$ confirmed the viability of production, $38 \%$ reported mixed results, and $19 \%$ found no economic feasibility. In particular, high variation was found in the case of poplar, for which the revenue value was the lowest, EUR $181 \mathrm{ha}^{-1}$ year $^{-1}$ on average, and the inter-quartile range was between EUR $66.9 \mathrm{ha}^{-1}$ year $^{-1}$ and EUR $193 \mathrm{ha}^{-1}$ year $^{-1}$. The revenue for willow was similar, at EUR $236 \mathrm{ha}^{-1}$ year $^{-1}$, and belonged to the same homogenous group (confirmed by the ANOVA results at $p>0.05$ ). In turn, the revenue from Miscanthus production was significantly higher (the second homogenous group) and reached approximately EUR $404 \mathrm{ha}^{-1}$ year $^{-1}$. The average internal rate of return (IRR) for all of the analyzed perennial crops stood at $15 \%$. The lowest value of the IRR was found for poplar $(11 \%)$, while it was $15 \%$ for Miscanthus and 18\% for willow.

\subsection{Analysis of Similarity}

The cluster analysis of the values of selected economic indicators enabled us to identify four areas where the economic conditions of perennial crop production were similar (Figure 8). The first area was Canada; the second the USA; the third was southern Europe represented by Italy; and the fourth comprised northern, western, and central Europe, represented by Sweden, Ireland, and Poland, respectively. Obviously, the selection of countries for our analysis was a result of a much higher frequency/number of papers published for the enumerated countries (Figure 2). On the other hand, this also attests to the interest in this subject among the researchers in these regions and, at the same time, indicates significant economic differences between them. 


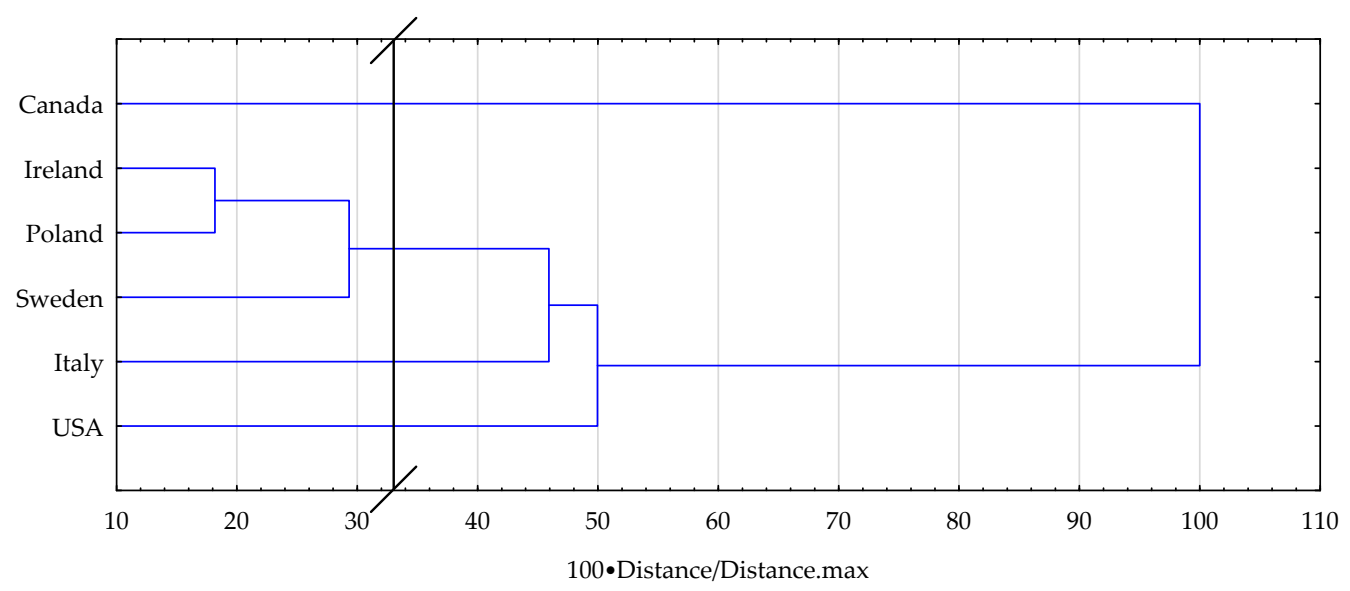

Figure 8. Cluster analysis of economic indicators in the papers selected for analysis.

\section{Conclusions}

Our analysis of the bibliographic data revealed three separate groups of research papers (clusters), of which the first included articles concerned with cultivation and price in relation to bioenergy, economic analysis, short rotation coppice, and net present value. The second cluster included papers investigating feedstock in terms of policy, reduction, and supply chain in the environmental performance approach. This approach was also close to the papers classified into the third cluster, dominated by the environmental aspects of energy, such as sustainability, life cycle assessment, heat, electricity, biogas, and power, with an emphasis on the analysis of Miscanthus. Over the years, a shift of interest has been noted from the purely economic approach, solely concentrated on the conditions of agricultural production, to sustainability analyses comprising the whole chain of biomass production, including policies and incentives.

The most frequently analyzed species of perennial crops were willow, poplar, and Miscanthus. The production costs of willow and poplar were similar, slightly over 500 EUR ha $^{-1}$ year $^{-1}$ for willow and 550 EUR ha $^{-1}$ year $^{-1}$ for poplar; in contrast, the production cost of Miscanthus was $70 \%$ higher, which was significantly more. However, the distribution of revenue was identical, as this value for willow and poplar stood at approximately $200 \mathrm{EUR} \mathrm{ha}^{-1}$ year $^{-1}$ and $180 \mathrm{EUR} \mathrm{ha}^{-1}$ year $^{-1}$; the revenue from Miscanthus was again much higher, at around $400 \mathrm{EUR} \mathrm{ha}^{-1}$ year $^{-1}$. The average sale prices were similar for all of the analyzed perennial crops. The results suggest that the conditions of production that determined the production cost were specific to the production needs of a particular crop, which had an essential impact on the possibility of achieving the expected revenue. On the other hand, the price of biomass was dictated by the market, independently of crops for energy. These mutual relations meant that growth in the revenue value should be sought in lowering the production cost or raising the crop yield. Another chance to increase the revenue could be created by incorporating biomass into the concept of bioeconomy, seeking opportunities of its cascading use primarily for the production of bioproducts of higher added value and only then using it for energy purposes; this is when the price of biomass can increase and the cost of production can decrease.

The production of perennial crops was regional in character and affected by various factors, mainly driven by the cost but most likely also by agricultural and climate conditions, which had an effect on crop yield. In Europe, the production conditions in the north differ from the economic situation in the south. The situation was no different in North America.

While we admit that a different wording of the key words used for selecting research papers would have enabled us to identify other papers on the relevant issues and may have resulted in different statistical values and clustering, the approach we adopted enabled us to create a multidimensional image of the economic issues of biomass production from perennial crops for energy purposes. Future studies should focus mainly on the 
environmental aspects of the external cost incurred in the production of biomass and generation of bioenergy.

Author Contributions: Conceptualization, E.O.-Z. and M.J.S.; methodology, E.O.-Z.; software, E.O.-Z.; validation, E.O.-Z., M.J.S. and M.K.; formal analysis, E.O.-Z.; investigation, E.O.-Z.; resources, E.O.-Z.; data curation, E.O.-Z.; statistical analysis; E.O.-Z.; writing-original draft preparation, E.O.-Z.; writing-review and editing, E.O.-Z., M.J.S. and M.K.; visualization, E.O.-Z.; supervision, E.O.-Z.; project administration, E.O.-Z. All authors have read and agreed to the published version of the manuscript.

Funding: The results presented in this paper were obtained as part of a comprehensive research project, funded by the University of Warmia and Mazury in Olsztyn, Faculty of Agriculture and Forestry, Department of Genetics, Plant Breeding and Bioresource Engineering (grant No. 30.610.007110 ) and co-financed by the National (Polish) Centre for Research and Development (NCBiR), entitled "Environment, agriculture and forestry", project: BIOproducts from lignocellulosic biomass derived from MArginal land to fill the Gap In Current national bioeconomy, No. BIOSTRATEG3/344253/2/ NCBR/2017.

Conflicts of Interest: The authors declare no conflict of interest.

\section{References}

1. Goor, F.; Jossart, J.M.; Ledent, J.F. ECOP: An economic model to assess the willow short rotation coppice global profitability in a case of small scale gasification pathway in Belgium. Environ. Model. Softw. 2000, 15, 279-292. [CrossRef]

2. Cook, J.; Beyea, J. Bioenergy in the United States: Progress and possibilities. Biomass Bioenergy 2000, 18, 441-455. [CrossRef]

3. Hall, D.O. Biomass energy in industrialised countries-A view of the future. For. Ecol. Manag. 1997, 91, 17-45. [CrossRef]

4. Fokaides, P.A.; Tofas, L.; Polycarpou, P.; Kylili, A. Sustainability aspects of energy crops in arid isolated island states: The case of Cyprus. Land Use Policy 2015, 49, 264-272. [CrossRef]

5. Pleguezuelo, C.R.R.; Zuazo, V.H.D.; Bielders, C.; Bocanegra, J.A.J.; Pereatorres, F.; Martínez, J.R.F. Bioenergy farming using woody crops-A review. Agron. Sustain. Dev. 2015, 35, 95-119. [CrossRef]

6. Glithero, J.N.; Wilson, P.; Ramsden, S.J. Optimal combinable and dedicated energy crop scenarios for marginal land. Appl. Energy 2015, 147, 82-91. [CrossRef]

7. Acuña, E.; Rubilar, R.; Cancino, J.; Albaugh, T.J.; Maier, C.A. Economic assessment of Eucalyptus globulus short rotation energy crops under contrasting silvicultural intensities on marginal agricultural land. Land Use Policy 2018, 76, 329-337. [CrossRef]

8. Liu, T.; Huffman, T.; Kulshreshtha, S.; McConkey, B.; Du, Y.; Green, M.; Jiangui, L.; Jiali, S.; Xiaoyuan, G. Bioenergy production on marginal land in Canada: Potential, economic feasibility, and greenhouse gas emissions impacts. Appl. Energy 2017, 205, 477-485. [CrossRef]

9. Nilsson, D.; Rosenqvist, H.; Bernesson, S. Profitability of the production of energy grasses on marginal agricultural land in Sweden. Biomass Bioenergy 2015, 83, 159-168. [CrossRef]

10. Schweier, J.; Becker, G. Economics of poplar short rotation coppice plantations on marginal land in Germany. Biomass Bioenergy 2013, 59, 494-502. [CrossRef]

11. Soldatos, P. Economic Aspects of Bioenergy Production from Perennial Grasses in Marginal Lands of South Europe. Bioenergy Res. 2015, 8, 1562-1573. [CrossRef]

12. Wagner, M.; Mangold, A.; Lask, J.; Petig, E.; Kiesel, A.; Lewandowski, I. Economic and environmental performance of miscanthus cultivated on marginal land for biogas production. GCB Bioenergy 2019, 11, 34-49. [CrossRef]

13. Wünsch, K.; Gruber, S.; Claupein, W. Profitability analysis of cropping systems for biogas production on marginal sites in southwestern Germany. Renew. Energy 2012, 45, 213-220. [CrossRef]

14. Philp, J. The Bioeconomy, the Challenge of the Century for Policy Makers. In New Biotechnology; Elsevier: Amsterdam, The Netherlands, 2018; Volume 40, pp. 11-19.

15. McKenney, D.W.; Yemshanou, D.; Fraleigh, S.; Allen, D.; Preto, F. An economic assessment of the use of short-rotation coppice woody biomass to heat greenhouses in southern Canada. Biomass Bioenergy 2011, 35, 374-384. [CrossRef]

16. Lantz, V.; Chang, W.Y.; Pharo, C. Benefit-cost analysis of hybrid willow crop production on agricultural land in eastern Canada: Assessing opportunities for on-farm and off-farm bioenergy use. Biomass Bioenergy 2014, 63, 257-267. [CrossRef]

17. Pereira, S.; Costa, M.; Carvalho, M.D.; Rodrigues, A. Potential of poplar short rotation coppice cultivation for bioenergy in Southern Portugal. Energy Convers. Manag. 2016, 125, 242-253. [CrossRef]

18. García-Velásquez, A.C.; Daza, L.; Cardona, C.A. Economic and Energy Valorization of Cassava Stalks as Feedstock for Ethanol and Electricity Production. BioEnergy Res. 2020, 13, 810-823. [CrossRef]

19. Khanna, M.; Dhungana, B.; Clifton-Brown, J. Costs of producing miscanthus and switchgrass for bioenergy in Illinois. Biomass Bioenergy 2008, 32, 482-493. [CrossRef]

20. Yuldashev, F.; Illukpitiya, P.; Tegegne, F.; Ekanem, E. Techno-economic analysis of plantation biomass production and small-scale wood pellet processing for bioenergy market. Int. Wood Prod. J. 2020, 11, 173-188. [CrossRef] 
21. Olba-Zięty, E.; Stolarski, M.J.; Krzyżaniak, M.; Gołaszewski, J. Environmental external cost of poplar wood chips sustainable production. J. Clean. Prod. 2020, 252, 119854. [CrossRef]

22. Auburger, S.; Jacobs, A.; Märländer, B.; Bahrs, E. Economic optimization of feedstock mix for energy production with biogas technology in Germany with a special focus on sugar beets-Effects on greenhouse gas emissions and energy balances. Renew. Energy 2016, 89, 1-11. [CrossRef]

23. Corno, L.; Pilu, R.; Tambone, F.; Scaglia, B.; Adani, F. New energy crop giant cane (Arundo donax L.) can substitute traditional energy crops increasing biogas yield and reducing costs. Bioresour. Technol. 2015, 191, 197-204. [CrossRef] [PubMed]

24. Yin, Y.J.; Ma, Z.C.; Nong, G.Z.; Wang, S.F. Strategies of energy management in a cassava starch plant for increasing energy and economic efficiency. J. Clean. Prod. 2019, 234, 1296-1305. [CrossRef]

25. Shooshtarian, A.; Anderson, J.A.; Armstrong, G.W.; Luckert, M.K. Growing hybrid poplar in western Canada for use as a biofuel feedstock: A financial analysis of coppice and single-stem management. Biomass Bioenergy 2018, 113, 45-54. [CrossRef]

26. Millinger, M.; Thran, D. Biomass price developments inhibit biofuel investments and research in Germany: The crucial future role of high yields. J. Clean. Prod. 2018, 172, 1654-1663. [CrossRef]

27. Forleo, M.B.; Palmieri, N.; Suardi, A.; Coaloa, D.; Pari, L. The eco-efficiency of rapeseed and sunflower cultivation in Italy. Joining environmental and economic assessment. J. Clean. Prod. 2018, 172, 3138-3153. [CrossRef]

28. Akgul, O.; Shah, N.; Papageorgiou, L.G. Economic optimisation of a UK advanced biofuel supply chain. Biomass Bioenergy 2012, 41, 57-72. [CrossRef]

29. Nguyen, T.T.L.; Gheewala, S.H.; Bonnet, S. Life cycle cost analysis of fuel ethanol produced from cassava in Thailand. Int. J. Life Cycle Assess. 2008, 13, 564-573. [CrossRef]

30. Brereton, N.J.B.; Berthod, N.; Lafleur, B.; Pedneault, K.; Pitre, F.E.; Labrecque, M. Extractable phenolic yield variation in five cultivars of mature short rotation coppice willow from four plantations in Quebec. Ind. Crop. Prod. 2017, 97, 525-535. [CrossRef]

31. Haveren, V.J.; Scott, E.L.; Sanders, J. Bulk chemicals from biomass. Biofuels Bioprod. Biorefining 2008, 2, 41-57. [CrossRef]

32. Malm, A.; Grzegorczyk, A.; Biernasiuk, A.; Baj, T.; Rój, E.; Tyśkiewicz, K.; Dębczak, A.; Stolarski, M.J.; Krzyżaniak, M.; Olba-Zięty, E. Could Supercritical Extracts from the Aerial Parts of Helianthus salicifolius A. Dietr. and Helianthus tuberosus L. Be Regarded as Potential Raw Materials for Biocidal Purposes? Agriculture 2020, 11, 10. [CrossRef]

33. Tyśkiewicz, K.; Konkol, M.; Kowalski, R.; Rój, E.; Warmiński, K.; Krzyżaniak, M.; Gil, Ł.; Stolarski, M.J. Characterization of bioactive compounds in the biomass of black locust, poplar and willow. Trees-Struct. Funct. 2019, 33, 1235-1263. [CrossRef]

34. Mola-Yudego, B.; Aronsson, P. Yield models for commercial willow biomass plantations in Sweden. Biomass Bioenergy 2008, 32, 829-837. [CrossRef]

35. Maaß, O.; Grundmann, P. Added-value from linking the value chains of wastewater treatment, crop production and bioenergy production: A case study on reusing wastewater and sludge in crop production in Braunschweig (Germany). Resour. Conserv. Recycl. 2016, 107, 195-211. [CrossRef]

36. Krzyzaniak, M.; Stolarski, M.J.; Waliszewska, B.; Szczukowski, S.; Tworkowski, J.; Załuski, D.; Śnieg, M. Willow biomass as feedstock for an integrated multi-product biorefinery. Ind. Crop. Prod. 2014, 58, 230-237. [CrossRef]

37. Manzone, M.; Airoldi, G.; Balsari, P. Energetic and economic evaluation of a poplar cultivation for the biomass production in Italy. Biomass Bioenergy 2009, 33, 1258-1264. [CrossRef]

38. Spinelli, R.; Magagnotti, N.; Lombardini, C.; Leonello, E.C. Cost-effective Integrated Harvesting of Short-Rotation Poplar Plantations. BioEnergy Res. 2021, 14, 460-468. [CrossRef]

39. Spinelli, R.; Cacot, E.; Mihelic, M.; Nestorovski, L.; Mederski, P.; Tolosana, E. Techniques and productivity of coppice harvesting operations in Europe: A meta-analysis of available data. Ann. For. Sci. 2016, 73, 1125-1139. [CrossRef]

40. Spinelli, R.; Magagnotti, N.; Picchi, G.; Lombardini, C.; Nati, C. Upsized Harvesting Technology for Coping with the New Trends in Short-Rotation Coppice. Appl. Eng. Agric. 2011, 27, 551-557. [CrossRef]

41. Spinelli, R.; Schweier, J.; de Francesco, F. Harvesting techniques for non-industrial SRF biomass plantations on farmland. J. Agric. Eng. 2013, 44, 5-9. [CrossRef]

42. Spinelli, R.; Schweier, J.; de Francesco, F. Harvesting techniques for non-industrial biomass plantations. Biosyst. Eng. 2012, 113, 319-324. [CrossRef]

43. Eisenbies, M.H.; Volk, T.A.; Souza, D.P.L.; Hallen, K.W. Cut-and-chip harvester material capacity and fuel performance on commercial-scale willow fields for varying ground and crop conditions. GCB Bioenergy 2020, 12, 380-395. [CrossRef]

44. Vanbeveren, S.P.P.; Magagnotti, N.; Spinelli, R. Increasing the Value Recovery from Short-Rotation Coppice Harvesting. Bioresources 2017, 12, 696-703. [CrossRef]

45. Vanbeveren, S.P.P.; Spinelli, R.; Eisenbies, M.; Schweier, J.; Mola-Yudego, B.; Magagnotti, N.; Acuna, M.; Dimitriou, I.; Ceulemans, R. Mechanised harvesting of short-rotation coppices. Renew. Sustain. Energy Rev. 2017, 76, 90-104. [CrossRef]

46. Vanbeveren, S.P.P.; Schweier, J.; Berhongaray, G.; Ceulemans, R. Operational short rotation woody crop plantations: Manual or mechanised harvesting? Biomass Bioenergy 2015, 72, 8-18. [CrossRef]

47. Vanbeveren, S.P.P.; De Francesco, F.; Ceulemans, R.; Spinelli, R. Productivity of mechanized whip harvesting with the Stemster MkIII in a short-rotation coppice established on farmland. Biomass Bioenergy 2018, 108, 323-329. [CrossRef]

48. Bergante, S.; Manzone, M.; Facciotto, G. Alternative planting method for short rotation coppice with poplar and willow. Biomass Bioenergy 2016, 87, 39-45. [CrossRef] 
49. O'Loughlin, J.; McDonnell, K.; Finnan, J. Quantifying the economic and greenhouse gas balance advantages of establishing miscanthus from stem cuttings. Biomass Bioenergy 2018, 109, 147-154. [CrossRef]

50. Amponsah, N.Y.; Troldborg, M.; Kington, B.; Aalders, I.; Hough, R.L. Greenhouse gas emissions from renewable energy sources: A review of lifecycle considerations. Renew. Sustain. Energy Rev. 2014, 39, 461-475. [CrossRef]

51. McCalmont, J.P.; Hastings, A.; McNamara, N.P.; Richter, G.M.; Robson, P.; Donnison, I.S.; Clifton-Brown, J. Environmental costs and benefits of growing Miscanthus for bioenergy in the UK. Glob. Chang. Biol. Bioenergy 2017, 9, 489-507. [CrossRef]

52. Perrin, A.; Wohlfahrt, J.; Morandi, F.; Ostergard, H.; Flatberg, T.; De la Rua, C.; Bjorkvoll, T.; Gabrielle, B. Integrated design and sustainable assessment of innovative biomass supply chains: A case-study on miscanthus in France. Appl. Energy 2017, 204, 66-77. [CrossRef]

53. Krzyżaniak, M.; Stolarski, M.J.; Szczukowski, S.; Tworkowski, J. Life Cycle Assessment of New Willow Cultivars Grown as Feedstock for Integrated Biorefineries. Bioenergy Res. 2016, 9, 224-238. [CrossRef]

54. Bender, M.; Tiedemann, M.; Teuber, L. Online and stochastic optimization for the harvesting of short rotation coppice. J. Clean. Prod. 2016, 110, 78-84. [CrossRef]

55. Hauk, S.; Skibbe, K.; Röhle, H.; Schröder, J.; Wittkopf, S.; Knoke, T. Nondestructive Estimation of Biomass Yield for Short-Rotation Woody Crops Is Reliable and Shows High Yields for Commercial Stands in Bavaria. BioEnergy Res. 2015, 8, 1401-1413. [CrossRef]

56. Salles, T.T.; Nogueira, D.A.; Beijo, L.A.; da Silva, L.F. Bayesian approach and extreme value theory in economic analysis of forestry projects. For. Policy Econ. 2019, 105, 64-71. [CrossRef]

57. Sleight, N.J.; Volk, T.A. Recently Bred Willow (Salix spp.) Biomass Crops Show Stable Yield Trends Over Three Rotations at Two Sites. BioEnergy Res. 2016, 9, 782-797. [CrossRef]

58. Sleight, N.J.; Volk, T.A.; Johnson, G.A.; Eisenbies, M.H.; Shi, S.; Fabio, E.S.; Pooler, P.S. Change in Yield Between First and Second Rotations in Willow (Salix spp.) Biomass Crops is Strongly Related to the Level of First Rotation Yield. Bioenergy Res. 2016, 9 , 270-287.

59. Havlíčková, K.; Weger, J.; Knápek, J. Modelling of biomass prices for bio-energy market in the Czech Republic. Simul. Model. Pract. Theory 2011, 19, 1946-1956. [CrossRef]

60. Frank, J.R.; Brown, T.R.; Volk, T.A.; Heavey, J.P.; Malmsheimer, R.W. A stochastic techno-economic analysis of shrub willow production using EcoWillow 3.0 S. Biofuels Bioprod. Biorefining 2018, 12, 846-856. [CrossRef]

61. Hunkeler, D.; Lichtenvort, K.; Rebitzer, G. Environmental Life Cycle Costing; CRC Press: New York, NY, USA, 2008 ; p. 191.

62. Martinho, V.J.P.D. Interrelationships between renewable energy and agricultural economics: An overview. Energy Strategy Rev. 2018, 22, 396-409. [CrossRef]

63. van Eck, N.J.; Waltman, L. VOSviewer Manual. 2021. Available online: https:/ /www.vosviewer.com/ (accessed on 17 August 2021).

64. Clancy, D.; Breen, J.P.; Thorne, F.; Wallace, M. A stochastic analysis of the decision to produce biomass crops in Ireland. Biomass Bioenergy 2012, 46, 353-365. [CrossRef]

65. Hauk, S.; Knoke, T.; Wittkopf, S. Economic evaluation of short rotation coppice systems for energy from biomass-A review. Renew. Sustain. Energy Rev. 2014, 29, 435-448. [CrossRef]

66. Stille, L.; Smeets, E.; Wicke, B.; Singh, R.; Singh, G. The economic performance of four (agro-) forestry systems on alkaline soils in the state of Haryana in India. Energy Sustain. Dev. 2011, 15, 388-397. [CrossRef]

67. Henseler, M.; Röder, N.; Liebersbach, H.; Kreins, P.; Osterburg, B. The mitigation potential and cost efficiency of abatement-based payments for the production of short-rotation coppices in Germany. Biomass Bioenergy 2015, 81, 592-601. [CrossRef]

68. Hauk, S.; Wittkopf, S.; Knoke, T. Analysis of commercial short rotation coppices in Bavaria, southern Germany. Biomass Bioenergy 2014, 67, 401-412. [CrossRef]

69. Testa, F.; Fabio, I.; Frey, M.; O'Connor, R. Life Cycle Costing, a View of Potential Applications: From Cost Management Tool to Eco-Efficiency Measurement. Supply Chain Manag. 2011. [CrossRef]

70. Testa, R.; Di Trapani, A.M.; Foderà, M.; Sgroi, F.; Tudisca, S. Economic evaluation of introduction of poplar as biomass crop in Italy. Renew. Sustain. Energy Rev. 2014, 38, 775-780. [CrossRef]

71. Sgroi, F.; Foderà, M.; Trapani, A.M.D.; Tudisca, S.; Testa, R. Economic evaluation of biogas plant size utilizing giant reed. Renew. Sustain. Energy Rev. 2015, 49, 403-409. [CrossRef]

72. Stolarski, M.J.; Stolarski, M.J.; Rosenqvist, H.; Krzyżaniak, M.; Szczukowski, S.; Tworkowski, J.; Gołaszewski, J.; Olba-Zięty, E. Economic comparison of growing different willow cultivars. Biomass Bioenergy 2015, 81, 210-215. [CrossRef]

73. Stolarski, M.J.; Olba-Zięty, E.; Rosenqvist, H.; Krzyżaniak, M. Economic efficiency of willow, poplar and black locust production using different soil amendments. Biomass Bioenergy 2017, 106, 74-82. [CrossRef]

74. Faber, A.; Pudelko, R.; Borek, R.; Borzecka-Walker, M.; Syp, A.; Krasuska, E.; Mathiou, P. Economic potential of perennial energy crops in Poland. J. Food Agric. Environ. 2012, 10, 1178-1182.

75. Krasuska, E.; Rosenqvist, H. Economics of energy crops in Poland today and in the future. Biomass Bioenergy 2012, 38, 23-33. [CrossRef]

76. Hoogwijk, M.; Faaij, A.; de Vries, B.; Turkenburg, W. Exploration of regional and global cost-supply curves of biomass energy from short-rotation crops at abandoned cropland and rest land under four IPCC SRES land-use scenarios. Biomass Bioenergy 2009, 33, 26-43. [CrossRef] 
77. Smeets, E.M.W.; Lewandowski, I.M.; Faaij, A.P.C. The economical and environmental performance of miscanthus and switchgrass production and supply chains in a European setting. Renew. Sustain. Energy Rev. 2009, 13, 1230-1245. [CrossRef]

78. Tharakan, P.J.; Volk, T.A.; Lindsey, C.A.; Abrahamson, L.P. Evaluating the impact of three incentive programs on the economics of cofiring willow biomass with coal in New York State. Energy Policy 2005, 33, 337-347. [CrossRef]

79. Buchholz, T.; Volk, T.A. Improving the Profitability of Willow Crops-Identifying Opportunities with a Crop Budget Model. BioEnergy Res. 2011, 4, 85-95. [CrossRef]

80. Langholtz, M.; Eaton, L.; Davis, M.; Shedden, M.; Brandt, C.; Volk, T.; Richard, T. Economic comparative advantage of willow biomass in the Northeast USA. Biofuels Bioprod. Biorefining 2019, 13, 74-85. [CrossRef]

81. Stanton, B.J.; Bourque, A.; Coleman, M.; Eisenbies, M.; Emerson, R.M.; Espinoza, J.; Gantz, C.; Himes, A.; Rodstrom, A.; Shuren, R.; et al. The practice and economics of hybrid poplar biomass production for biofuels and bioproducts in the Pacific Northwest. Bioenergy Res. 2021, 14, 543-560. [CrossRef]

82. Yemshanov, D.; McKenney, D. Fast-growing poplar plantations as a bioenergy supply source for Canada. Biomass Bioenergy 2008, 32, 185-197. [CrossRef]

83. Mantziaris, S.; Iliopoulos, C.; Theodorakopoulou, I.; Petropoulou, E. Perennial energy crops vs. durum wheat in low input lands: Economic analysis of a Greek case study. Renew. Sustain. Energy Rev. 2017, 80, 789-800. [CrossRef]

84. Ericsson, K.; Rosenqvist, H.; Ganko, E.; Pisarek, M.; Nilsson, L. An agro-economic analysis of willow cultivation in Poland. Biomass Bioenergy 2006, 30, 16-27. [CrossRef]

85. Styles, D.; Jones, M.B. Energy crops in Ireland: Quantifying the potential life-cycle greenhouse gas reductions of energy-crop electricity. Biomass Bioenergy 2007, 31, 759-772. [CrossRef]

86. Witzel, C.-P.; Finger, R. Economic evaluation of Miscanthus production-A review. Renew. Sustain. Energy Rev. 2016, 53, 681-696. [CrossRef]

87. Xue, S.; Kalinina, O.; Lewandowski, I. Present and future options for Miscanthus propagation and establishment. Renew. Sustain. Energy Rev. 2015, 49, 1233-1246. [CrossRef]

88. El Kasmioui, O.; Ceulemans, R. Financial analysis of the cultivation of poplar and willow for bioenergy. Biomass Bioenergy 2012, 43, 52-64. [CrossRef]

89. Volk, T.A.; Abrahamson, L.P.; Nowak, C.A.; Smart, L.B.; Tharakan, P.J.; White, E.H. The development of short-rotation willow in the northeastern United States for bioenergy and bioproducts, agroforestry and phytoremediation. Biomass Bioenergy 2006, 30, 715-727. [CrossRef]

90. Rosenqvist, H.; Berndes, G.; Börjesson, P. The prospects of cost reductions in willow production in Sweden. Biomass Bioenergy 2013, 48, 139-147. [CrossRef]

91. Konstantinavičienė, J.; Varnagirytė-Kabašinskienė, I.; Škėma, M.; Aleinikovas, M. Assessment of the socio-economic factors affecting the development of willow energy plantations in Lithuania. Balt. For. 2020, 26, 1-8. [CrossRef]

92. Stadig, L.M.; Tuyttens, F.A.M.; Rodenburg, T.B.; Verdonckt, P.; Wauters, E.; Borremans, L.; Reubens, B. Opportunities for short rotation coppice production on free-range chicken farms in Flanders: Farmers' perceptions and cost-benefit analysis. Renew. Agric. Food Syst. 2020, 35, 286-295. [CrossRef]

93. Schiberna, E.; Borovics, A.; Benke, A. Economic Modelling of Poplar Short Rotation Coppice Plantations in Hungary. Forests 2021, 12, 623. [CrossRef]

94. Faasch, R.J.; Patenaude, G. The economics of short rotation coppice in Germany. Biomass Bioenergy 2012, 45, 27-40. [CrossRef]

95. Fazio, S.; Barbanti, L. Energy and economic assessments of bio-energy systems based on annual and perennial crops for temperate and tropical areas. Renew. Energy 2014, 69, 233-241. [CrossRef]

96. Styles, D.; Thorne, F.; Jones, M.B. Energy crops in Ireland: An economic comparison of willow and Miscanthus production with conventional farming systems. Biomass Bioenergy 2008, 32, 407-421. [CrossRef]

97. Volk, T.A.; Heavey, J.P.; Eisenbies, M.H. Advances in shrub-willow crops for bioenergy, renewable products, and environmental benefits. Food Energy Secur. 2016, 5, 97-106. [CrossRef]

98. Stanturf, J.A.; Young, T.M.; Perdue, J.H.; Doughetry, D.; Pigott, M.; Guo, Z.; Huang, X. Potential Profitability Zones for Populus spp. Biomass Plantings in the Eastern United States. For. Sci. 2017, 63, 586-595.

99. Dimitriou, I.; Rosenqvist, H. Sewage sludge and wastewater fertilisation of Short Rotation Coppice (SRC) for increased bioenergy production-Biological and economic potential. Biomass Bioenergy 2011, 35, 835-842. [CrossRef]

100. Dumortier, J. Impact of agronomic uncertainty in biomass production and endogenous commodity prices on cellulosic biofuel feedstock composition. GCB Bioenergy 2016, 8, 35-50. [CrossRef]

101. San Miguel, G.; Corona, B.; Ruiz, D.; Landholm, D.; Laina, R.; Tolosana, E.; Sixto, H.; Cañellas, I. Environmental, energy and economic analysis of a biomass supply chain based on a poplar short rotation coppice in Spain. J. Clean. Prod. 2015, 94, 93-101. [CrossRef]

102. Vyn, R.J.; Virani, T.; Deen, B. Examining the economic feasibility of miscanthus in Ontario: An application to the greenhouse industry. Energy Policy 2012, 50, 669-676. [CrossRef]

103. De Laporte, A.V.; Weersink, A.J.; McKenney, D.W. A spatial model of climate change effects on yields and break-even prices of switchgrass and miscanthus in Ontario, Canada. GCB Bioenergy 2014, 6, 390-400. [CrossRef]

104. Dumortier, J.; Kauffman, N.; Hayes, D.J. Production and spatial distribution of switchgrass and miscanthus in the United States under uncertainty and sunk cost. Energy Econ. 2017, 67, 300-314. [CrossRef] 
105. Sorică, E. Analysis of profitability of implementing the miscanthus energetic crop technology for rhizomes capitalization. INMATEH-Agric. Eng. 2015, 46, 155-164.

106. Allen, D.; McKenney, D.W.; Yemshanov, D.; Fraleigh, S. The economic attractiveness of short rotation coppice biomass plantations for bioenergy in Northern Ontario. For. Chron. 2013, 89, 66-78. [CrossRef]

107. Krzyżaniak, M.; Stolarski, M.J.; Warmiński, K. Life cycle assessment of poplar production: Environmental impact of different soil enrichment methods. J. Clean. Prod. 2019, 206, 785-796. [CrossRef]

108. Krzyżaniak, M.; Stolarski, M.J.; Warmiński, K. Life Cycle Assessment of Giant Miscanthus: Production on Marginal Soil with Various Fertilisation Treatments. Energies 2020, 13, 1931. [CrossRef]

109. Pizzol, M.; Weidema, B.; Brandão, M.; Osset, P. Monetary valuation in Life Cycle Assessment: A review. J. Clean. Prod. 2015, 86, 170-179. [CrossRef]

110. Pizzol, M.; Laurent, A.; Sala, S.; Weidema, B.; Verones, F.; Koffler, C. Normalisation and weighting in life cycle assessment: Quo vadis? Int. J. Life Cycle Assess. 2017, 22, 853-866. [CrossRef]

111. Stolarski, M.J.; Krzyżaniak, M.; Warmiński, K.; Załuski, D.; Olba-Zięty, E. Willow Biomass as Energy Feedstock: The Effect of Habitat, Genotype and Harvest Rotation on Thermophysical Properties and Elemental Composition. Energies 2020, 13, 4130. [CrossRef]

112. Olba-Zięty, E.; Stolarski, M.J.; Krzyżaniak, M.; Warmiński, K. Willow Cultivation as Feedstock for Bioenergy-External Production Cost. Energies 2020, 13, 4799. [CrossRef]

113. Neugebauer, S.; Forin, S.; Finkbeiner, M. From life cycle costing to economic life cycle assessment-introducing an economic impact pathway. Sustainability 2016, 8, 428. [CrossRef]

114. Musshoff, O. Growing short rotation coppice on agricultural land in Germany: A Real Options Approach. Biomass Bioenergy 2012, 41, 73-85. [CrossRef]

115. Regan, C.M.; Connor, J.D.; Raja Segaran, R.; Meyer, W.S.; Bryan, B.A.; Ostendorf, B. Climate change and the economics of biomass energy feedstocks in semi-arid agricultural landscapes: A spatially explicit real options analysis. J. Environ. Manag. 2017, 192, 171-183. [CrossRef] [PubMed]

116. Buchholz, T.; Volk, T. Profitability of Willow Biomass Crops Affected by Incentive Programs. BioEnergy Res. 2013, 6, 53-64. [CrossRef]

117. Ridier, A. Farm Level Supply of Short Rotation Woody Crops: Economic Assessment in the Long-Term for Household Farming Systems. Can. J. Agric. Econ. 2012, 60, 357-375. [CrossRef]

118. Miao, R.; Khanna, M. Effectiveness of the biomass crop assistance program: Roles of behavioral factors, credit constraint, and program design. Appl. Econ. Perspect. Policy 2017, 39, 584-608. [CrossRef]

119. Ascenso, L.; d'Amore, F.; Carvalho, A.; Bezzo, F. Assessing multiple biomass-feedstock in the optimization of power and fuel supply chains for sustainable mobility. Chem. Eng. Res. Des. 2018, 131, 127-143. [CrossRef]

120. Knoke, T.; Hildebrandt, P.; Klein, D.; Mujica, R.; Moog, M.; Mosandl, R. Financial compensation and uncertainty: Using mean-variance rule and stochastic dominance to derive conservation payments for secondary forests. Can. J. For. Res. 2008, 38, 3033-3046. [CrossRef]

121. Skevas, T.; Swinton, S.M.; Tanner, S.; Sanford, G.; Thelen, K.D. Investment risk in bioenergy crops. Glob. Chang. Biol. Bioenergy 2016, 8, 1162-1177. [CrossRef]

122. Hauk, S.; Gandorfer, M.; Wittkopf, S.; Muller, U.K.; Knoke, T. Ecological diversification is risk reducing and economically profitable-The case of biomass production with short rotation woody crops in south German land-use portfolios. Biomass Bioenergy 2017, 98, 142-152. [CrossRef] 